\title{
Smoke Control using a Double-skin Facade
}

\author{
WENTING DING ${ }^{1}$, YUJI HASEMI ${ }^{1}$ and TOKIYOSHI YAMADA ${ }^{2}$ \\ ${ }^{1}$ Department of Architecture, Waseda University \\ Okubo-3 \\ Shinjuku-ku, Tokyo 169-8555, Japan \\ ${ }^{2}$ National Research Institute of Fire and Disaster \\ Nakahara 3 chome \\ Mitaka, Tokyo 181-8633, Japan
}

\begin{abstract}
Double-skin façades have been increasingly used as they open up new possibilities for clients and planners seeking creative new designs that are intelligently adapted to environmental conditions. Among them natural ventilation is commonly carried out in a building with double-skin facades. However double-skin façade construction is still not covered by statutory building regulations. Virtually no information exists on the behavior of this kind of façade in case of a fire. Usually for a building with a multistory double-skin façade, smoke of a fire room escaping through the inner façade into the intermediate space between the two skins may accumulate and spread horizontally and/or vertically to other rooms that have openings connected to the intermediate space for the purpose of natural ventilation. However if smoke pressure in the intermediate space can be kept lower than that of the room, smoke spread through the openings will be prevented. Considering similarity of smoke movement and stack natural ventilation, in this paper a double-skin façade used for natural ventilation is also considered for smoke control. As the results, it is proved that smoke spread can be prevented with suitable opening arrangements. Therefore natural ventilation and smoke control can be realized through one system. Reduced scale model experiments and computational fluid dynamics (CFD) analysis are carried out in this research.
\end{abstract}

KEYWORDS: smoke control, double-skin facade, natural ventilation system, solar chimney, model experiments

\section{INTRODUCTION}

To reduce global environmental damage and pursue high quality indoor conditions in office buildings, double-skin façade is getting more and more attention as it provides many possibilities for energy conservation and at the same time creates good indoor environment $[1,2,3]$. However double-skin façade construction is still not covered by statutory building regulations. Virtually no information exists on the behavior of this kind of façade in case of a fire. Usually for a building with a multistory double-skin façade, smoke of a fire room escaping through the inner façade into the intermediate space between the two skins may accumulate and spread horizontally and/or vertically to other rooms that have openings to the intermediate space for the purpose of natural ventilation.

Actually for natural ventilated buildings, as there are opening paths existing throughout the whole buildings, when a fire happens, the opening paths for natural ventilation also become paths for smoke to spread to other non-fire spaces. This is always pointed out as the weakness of natural ventilated buildings. However stack ventilation and smoke movement are both driven by stack effect which enlightens us the possibility of using the same system to handle these two problems. It has been proved that for a natural ventilated atrium building with a solar chimney on top of the atrium, natural ventilation and smoke 
control can be realized through the same system [4,5]. Similarly it is also possible to deal with smoke problem and natural ventilation using the same system for buildings with double-skin facades. Actually as long as smoke pressure in the double-skin space can be kept lower than that of the occupant space, smoke spread through the openings for natural ventilation will be prevented.

\section{PROTOTYPE BUILDING}

\section{Outline of the Prototype Building}

A prototype building is proposed to make further discussions (Fig. 1). It is thought to be an 8-storey office building with an atrium space in the north side. Staircase and utility space are contained in the atrium. The south façade of the building is a double-skin façade and a 3-storey high thermal storage space called solar chimney is considered above the double-skin space to strengthen stack effect. Actually the double-skin space is connected with the chimney channel.
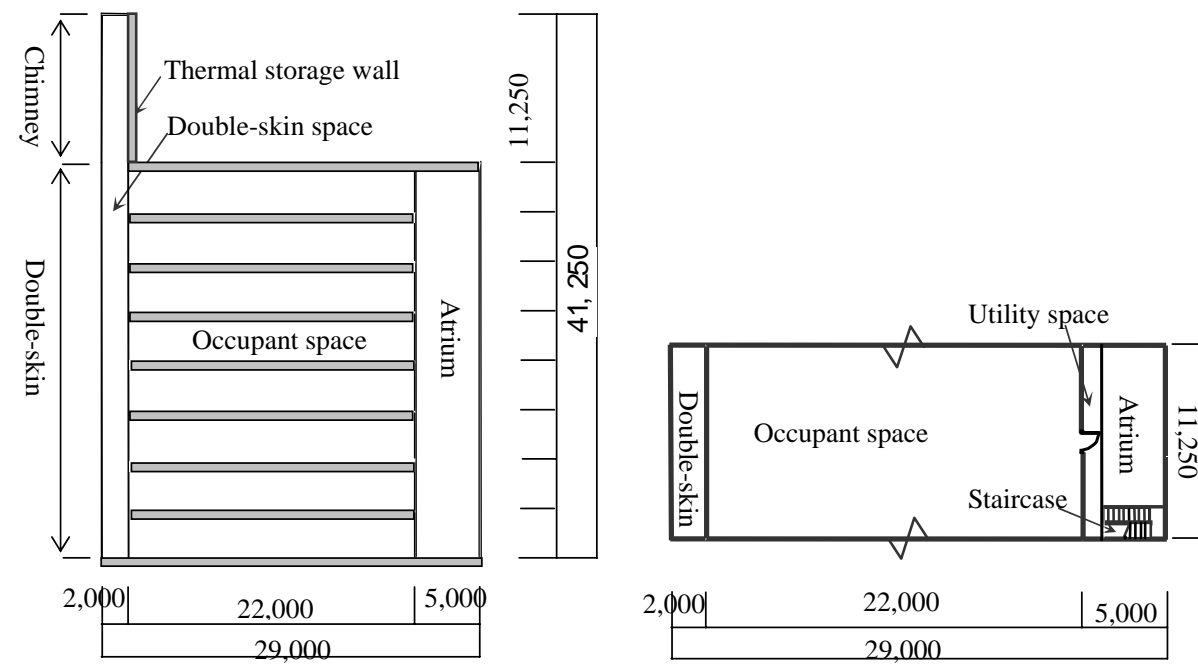

Fig. 1. Outline of the prototype building (Left: Plan; Right: Section; Units: mm).

\section{Natural Ventilation in the Prototype Building}

The south-facing wall of the solar chimney is considered as a thermal storage wall. Solar radiation passes through the outer glazing of the double-skin facade and the chimney; air inside the double-skin space and the chimney channel is warmed up. With moderate setting of openings, natural ventilation throughout the building is activated by stack effect as shown in Fig. 2. Fresh air is taken in from openings between the atrium and outside, passes through the occupant space and is discharged into the double-skin space. It is finally exhausted from the outlet on top of the chimney. As long as pressure of the double-skin space is lower than that of the atrium even at the top floor height, natural ventilation of all the occupant space can be realized.

\section{Smoke Control in the Prototype Building}

When a fire breaks out in any office room, smoke may leak into the double-skin space or atrium space. For the purpose of natural ventilation, openings between outside and the 
atrium, the atrium and occupant space, the occupant space and double-skin space, the double-skin space and outside are located respectively. Considering openings between outside and the atrium serve as fresh air supply, smoke flows into the double-skin space. It is accumulated in the chimney space and at the same time exhausted from the openings on top of the chimney. It is predicted that smoke layer will descend to below the occupant space due to small volume of the solar chimney. However, as long as pressure of the double-skin space can be kept lower than that of the atrium space even at the top floor height as shown in Fig. 3, smoke accumulated in the double-skin space will not invade into the occupant space.

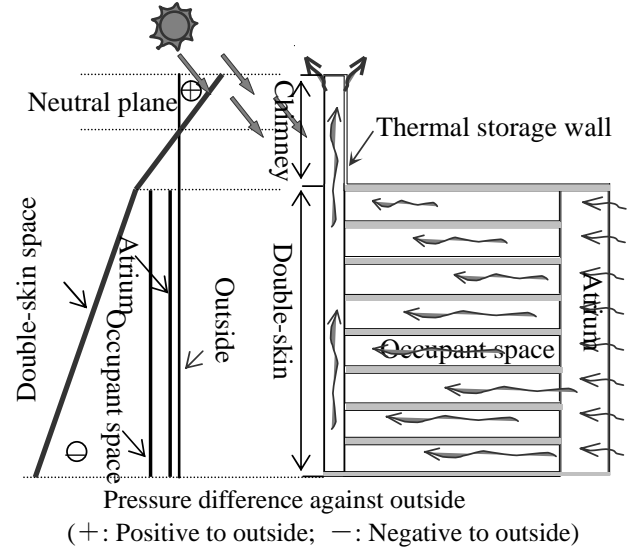

Fig. 2. Concept of natural ventilation.

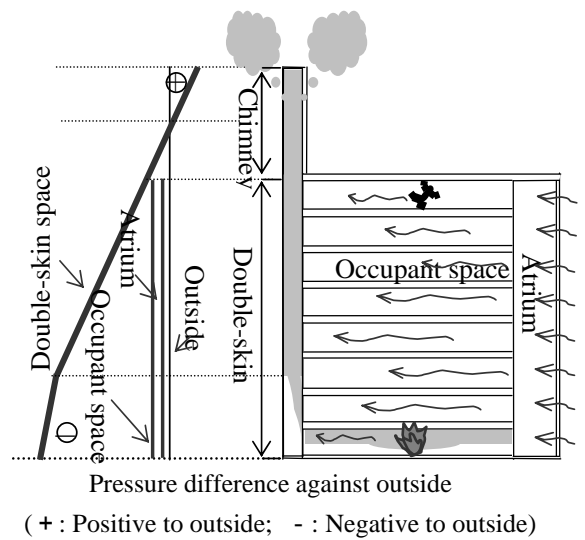

Fig. 3. Concept of smoke control.

As the first stage of this research, natural ventilation performance of the double-skin façade has been discussed [6]. It is proved preferable ventilation can be obtained in all of the occupant space with moderate opening conditions. In this paper conditions for how to prevent smoke propagation to the occupant space will be examined. Reduced scale model experiments and computational fluid dynamics (CFD) analysis are carried out.

\section{MODEL EXPERIMENTS}

\section{Scale Modeling}

If the heat generated from fire source $Q$ is all transported by convection, it can be calculated as

$Q=C_{p} m_{v} \Delta T$

where $\Delta T$ is the temperature rise due to fire.

Furthermore, if the convection is natural, the mass flow rate $m_{v}$ can be expressed as

$m_{v} \propto A_{v e n t}(2 \rho \Delta p)^{1 / 2}$ 
where $\mathrm{A}_{\text {vent }}$ is the vent area and $\Delta p$ is pressure difference which can be calculated as:

$$
\Delta p=\Delta \rho g H
$$

where $H$ is height and $\rho$ is density. Letting $l$ be characteristic length, we got

$$
A_{\text {vent }} \propto l^{2}
$$

and

$$
H \propto l
$$

Therefore

$m_{v} \propto l^{5 / 2}$

and

$Q \propto l^{5 / 2} \Delta T$

If the temperatures are maintained same between real $(\mathrm{F})$ and reduced scale $(M)$ tests, i.e.

$$
\Delta T_{M}=\Delta T_{F}
$$

In this case, naturally $\Delta \rho_{M}=\Delta \rho_{F}$, therefore,

$$
\frac{\Delta p_{M}}{\Delta p_{F}}=\frac{l_{M}}{l_{F}}
$$

and the heat release rates of real and reduced scale should be

$$
\frac{Q_{M}}{Q_{F}}=\left(\frac{l_{M}}{l_{F}}\right)^{5 / 2}
$$

Although the similarity law by Eq. 10 neglects other phenomena including heat transfer, we use Eq. 10 to determine the heat release rate in the model experiments.

\section{Description of the Experimental Model}

The experimental model is the same as that used for natural ventilation experiments. Considering manual operability of the experiments and similarity of the basic characteristic of the flow in the reduced scale model and the full-scale prototype building, the experimental model is reproduced as $1 / 25$ of the full-scale prototype building. Figure 4 shows outline of the experimental model. 

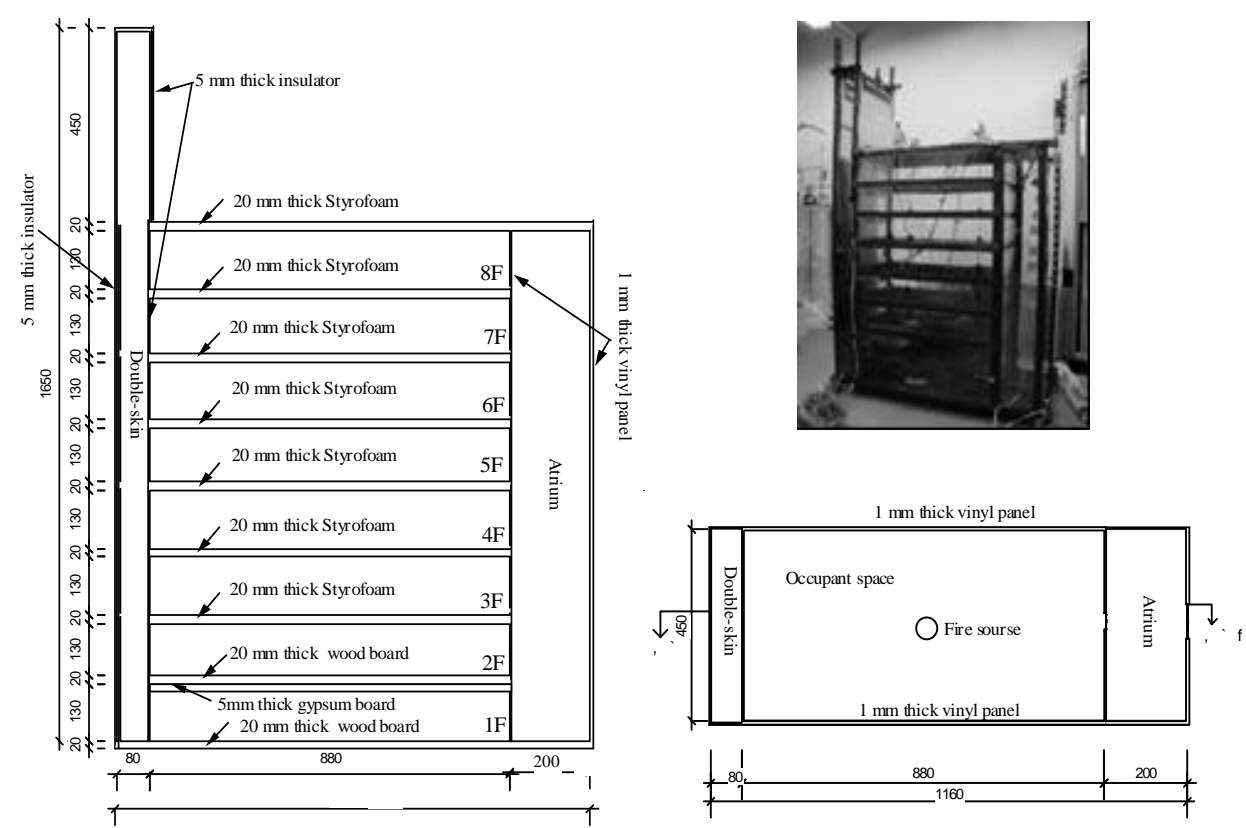

Fig. 4. Outline of the experimental model.(Left: A-A section; Right upper: Picture; Right lower: plan; Units: mm).

\section{Experimental Conditions}

To realize preferable airflow throughout the building, setting of openings should be reasonably planned. Openings between outside and the atrium allow fresh air flowing into the atrium. Door between atrium and occupant space is considered as opening for ventilation and its area is assumed as $2 \mathrm{~m}^{2}$ on each floor. Openings between the occupant space and double-skin space allow air/smoke discharged into the double-skin space and finally exhausted from openings on top of the chimney. Figure 5 shows arrangement of the openings and experiments with several opening conditions are carried out (Table 1).

Considering a fire happens at the first floor, ethanol is used as the fire source and put in a shallow metal dish with the diameter of $4.5 \mathrm{~cm}$. The dish is put on the bottom of the base floor and just in the center position (Fig. 4). Temperatures in the double-skin space, occupant space and atrium, pressure distribution in the double-skin space are measured during all of the experiments (Fig. 5). Smoke stick is used to make the smoke movement visualized. Assuming an initial real fire with heat release rate of 3MW, it will be reproduced as about $960 \mathrm{~W}$ in the experiments according to the scale modeling. In each experiment $15 \mathrm{ml}$ ethanol is burned and the time-averaged heat release rate can be calculated as:

$q=\frac{\rho V \Delta H_{C}}{t}$

where $q$ is time-averaged heat release rate, $\mathrm{kW} ; \rho$ is density of ethanol, $\mathrm{kg} / \mathrm{m}^{3} ; V$ is volume of burned ethanol, $\mathrm{m}^{3} ; \Delta H_{c}$ is effective heat of combustion of ethanol, $\mathrm{kJ} / \mathrm{kg} ; t$ is burning time, s. According to the results of the experiments, time-averaged heat release rate of the fire source is about $880 \mathrm{~W}$ which equals to a real fire of around $2.7 \mathrm{MW}$. 


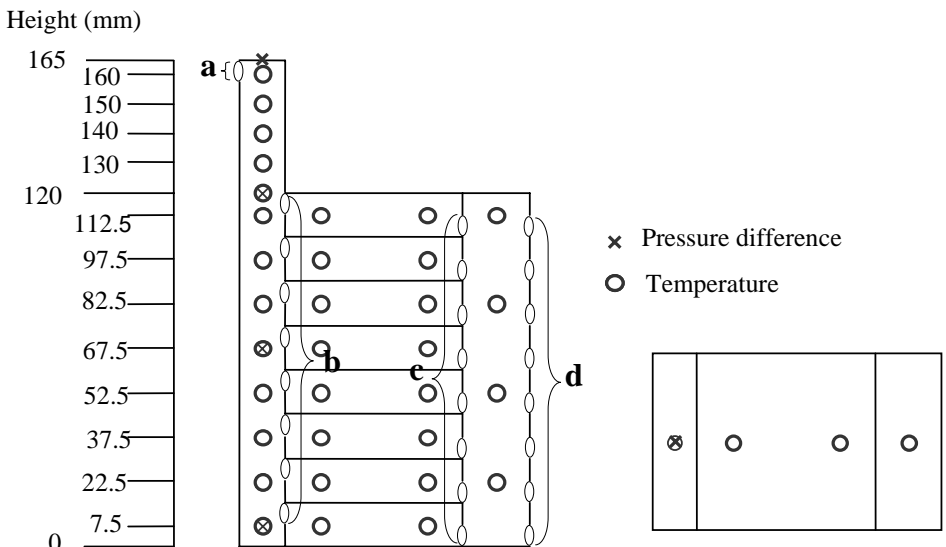

Fig. 5. Arrangement of openings and measuring points.

Table 1. Experimental condition of openings.

\begin{tabular}{|c|c|c|c|c|}
\hline \multirow{2}{*}{ Case } & \multicolumn{4}{|c|}{ Setting of openings } \\
\hline & $\mathbf{a}$ & b & C & d \\
\hline S_A4D4 & $\begin{array}{c}32 \mathrm{~cm} \times 2 \mathrm{~cm} \\
\left(4 \mathrm{~m}^{2}\right)\end{array}$ & \multirow{5}{*}{$\begin{array}{c}16 \mathrm{~cm} \times 2 \mathrm{~cm} \times 8 \mathrm{~F} \\
\left(2 \mathrm{~m}^{2} \times 8 \mathrm{~F}=16\right. \\
\left.\mathrm{m}^{2}\right)\end{array}$} & \multirow{5}{*}{$\begin{array}{c}8 \mathrm{~cm} \times 4 \mathrm{~cm} \times 8 \mathrm{~F} \\
\left(2 \mathrm{~m}^{2} \times 8 \mathrm{~F}=16\right. \\
\left.\mathrm{m}^{2}\right)\end{array}$} & $\begin{array}{c}4 \mathrm{~cm} \times 2 \mathrm{~cm} \times 8 \mathrm{~F} \\
\left(1 \mathrm{~m}^{2} \times 8 \mathrm{~F}=4 \mathrm{~m}^{2}\right)\end{array}$ \\
\hline S_A8D4 & $\begin{array}{c}32 \mathrm{~cm} \times 2 \mathrm{~cm} \times 2 \\
\left(4 \mathrm{~m}^{2} \times 2\right)\end{array}$ & & & $\begin{array}{c}4 \mathrm{~cm} \times 2 \mathrm{~cm} \times 8 \mathrm{~F} \\
\left(1 \mathrm{~m}^{2} \times 8 \mathrm{~F}=4 \mathrm{~m}^{2}\right)\end{array}$ \\
\hline S_A8D8 & $\begin{array}{c}32 \mathrm{~cm} \times 2 \mathrm{~cm} \times 2 \\
\left(4 \mathrm{~m}^{2} \times 2\right)\end{array}$ & & & $\begin{array}{c}4 \mathrm{~cm} \times 4 \mathrm{~cm} \times 8 \mathrm{~F} \\
\left(1 \mathrm{~m}^{2} \times 8 \mathrm{~F}=8 \mathrm{~m}^{2}\right)\end{array}$ \\
\hline S_A16D8 & $\begin{array}{c}32 \mathrm{~cm} \times 4 \mathrm{~cm} \times 2 \\
\left(8 \mathrm{~m}^{2} \times 2\right)\end{array}$ & & & $\begin{array}{c}4 \mathrm{~cm} \times 4 \mathrm{~cm} \times 8 \mathrm{~F} \\
\left(1 \mathrm{~m}^{2} \times 8 \mathrm{~F}=8 \mathrm{~m}^{2}\right)\end{array}$ \\
\hline S_A16D16 & $\begin{array}{c}32 \mathrm{~cm} \times 4 \mathrm{~cm} \times 2 \\
\left(8 \mathrm{~m}^{2} \times 2\right)\end{array}$ & & & $\begin{array}{c}8 \mathrm{~cm} \times 4 \mathrm{~cm} \times 8 \mathrm{~F} \\
\left(2 \mathrm{~m}^{2} \times 8 \mathrm{~F}=16\right. \\
\left.\mathrm{m}^{2}\right)\end{array}$ \\
\hline
\end{tabular}

*( ) represents full-scale value.

\section{NUMERICAL MODELING}

Although airflow conditions can be grasped through the model experiments in some degree, there are still many unknown factors existing in the experiments due to limitations of the testing instruments and model scale. Therefore numerical calculation is also conducted to contrast with the experimental results.

The numerical simulations for this research are done using a general three-dimensional computational fluid dynamics (CFD) model. Standard $\kappa-\varepsilon$ model is used and the upwind scheme has been adopted in the simulation.

The computational domain is basically divided into a grid of $0.03 \mathrm{~m} \times 0.03 \mathrm{~m} \times 0.03 \mathrm{~m}$ control volumes (Grid independence tests are conducted, which demonstrates that a gird of $0.03 \mathrm{~m} \times 0.03 \mathrm{~m} \times 0.03 \mathrm{~m}$ control volume is sufficient to get appropriate results). Additional grid points are embedded near the walls, around the openings to enable better resolution in these areas. 
Thermal properties of all the walls and floors are set as those of the experimental model. Opening conditions are also set as the same as those of the experiments (Table 1). A cylinder volumetric heat source is used to reproduce the fire source whose diameter is set to be $4.5 \mathrm{~cm}$ and height is set as [7]:

$Z_{f}=0.08 Q^{2 / 5}$

where $Q$ is heat release rate of the fire source in the experiments, which is set as the calculated value according to Eq. 11 based on the experimental results.

\section{COMPARISON OF CFD AND EXPERIMENTAL RESULTS}

All of the results show temperature rise of the simulation is somewhat higher than that of the experiments. One of the reasons can be considered as low air tightness of the experimental model. While for the simulation model, no heat will be lost due to existing of gaps.

In the experiments, pressure differences between outside and the double-skin space are measured at four points. Pressure differences between outside and the atrium are also illustrated in the figure according to the simulation results. In addition, predicted velocity vector diagrams of openings by CFD are shown besides the pressure difference figures.

When openings between outside and the atrium are set as $4 \mathrm{~m}^{2}\left(0.5 \mathrm{~m}^{2}\right.$ each floor), temperature distribution in the double-skin space has no obvious difference by changing the opening areas on top of the chimney. In Case S_A4D4, pressure of the atrium at upper floors are lower than that of the double-skin space, that means smoke may flow from the double-skin space to atrium. In Case S_A8D4, pressure of the atrium at upper floors are still lower than that of the double-skin space, that means smoke may propagate to the occupant space of upper floors. This condition could not be improved even with making opening areas on top of the chimney larger. Simulations results show smoke invades into the eighth floor occupant space in both Case S_A4D4 and Case S_A8D4.

When openings between outside and the atrium are set as $8 \mathrm{~m}^{2}\left(1 \mathrm{~m}^{2}\right.$ each floor), pressure of the atrium space at the top floor is lower than that of the double-skin space in Case S_A8D8. Simulation result shows smoke invades into the occupant space. While when the openings on top of the chimney become two times of the openings between outside and the atrium in Case S_A16D8, pressure of the double-skin space at the top floor becomes lower than that of the atrium. Therefore smoke accumulated in the double-skin space will not invade into the occupant space. Simulation result also shows there is no smoke invading into the occupant space.

Moreover when openings between outside and the atrium are set as $16 \mathrm{~m}^{2}\left(2 \mathrm{~m}^{2}\right.$ each floor), as shown in Case S_A16D16, pressure of the double-skin space is greater than that of the atrium at any height of the occupant space. That means smoke propagation to the occupant space will be prevented.

Smoke stick is used in the experiments to visualize smoke movement. Some experimental pictures are shown in Fig. 7. In case S_A4D4 smoke accumulated in the double-skin space invaded into the upper floors which corresponded to the pressure difference relation shown in Fig. 6. In Case S_A8D8 faint smoke was observed in the top occupant space while in Case S_A16D16, no smoke invaded into the occupant space.

As mentioned above, natural ventilation performance of the double-skin space has been 
discussed at the first stage of this research [6]. As the results, To ensure preferable airflow in the occupant space even at the top floor, opening areas between outside and the atrium are recommended to not less than $16 \mathrm{~m}^{2}\left(2 \mathrm{~m}^{2}\right.$ each floor). Therefore openings between the atrium and outside of not less than $16 \mathrm{~m}^{2}$ will satisfy the requirement for both natural ventilation and smoke control.

In this paper a first fire condition has been assumed to make discussions. As the results hot plume temperature is below $150^{\circ} \mathrm{C}$ and does not exceed the heat-resistant temperature of the glass. However when the fire develops to become larger, high temperature flame ejected from the fire room reaches the exterior façade of the double-skin which may cause the collapse of the exterior façade. Under such conditions the double-skin façade actually becomes outside and smoke of the fire room may invade into the atrium space. Therefore it is necessary to finish the whole building refuge before the exterior façade breaks.
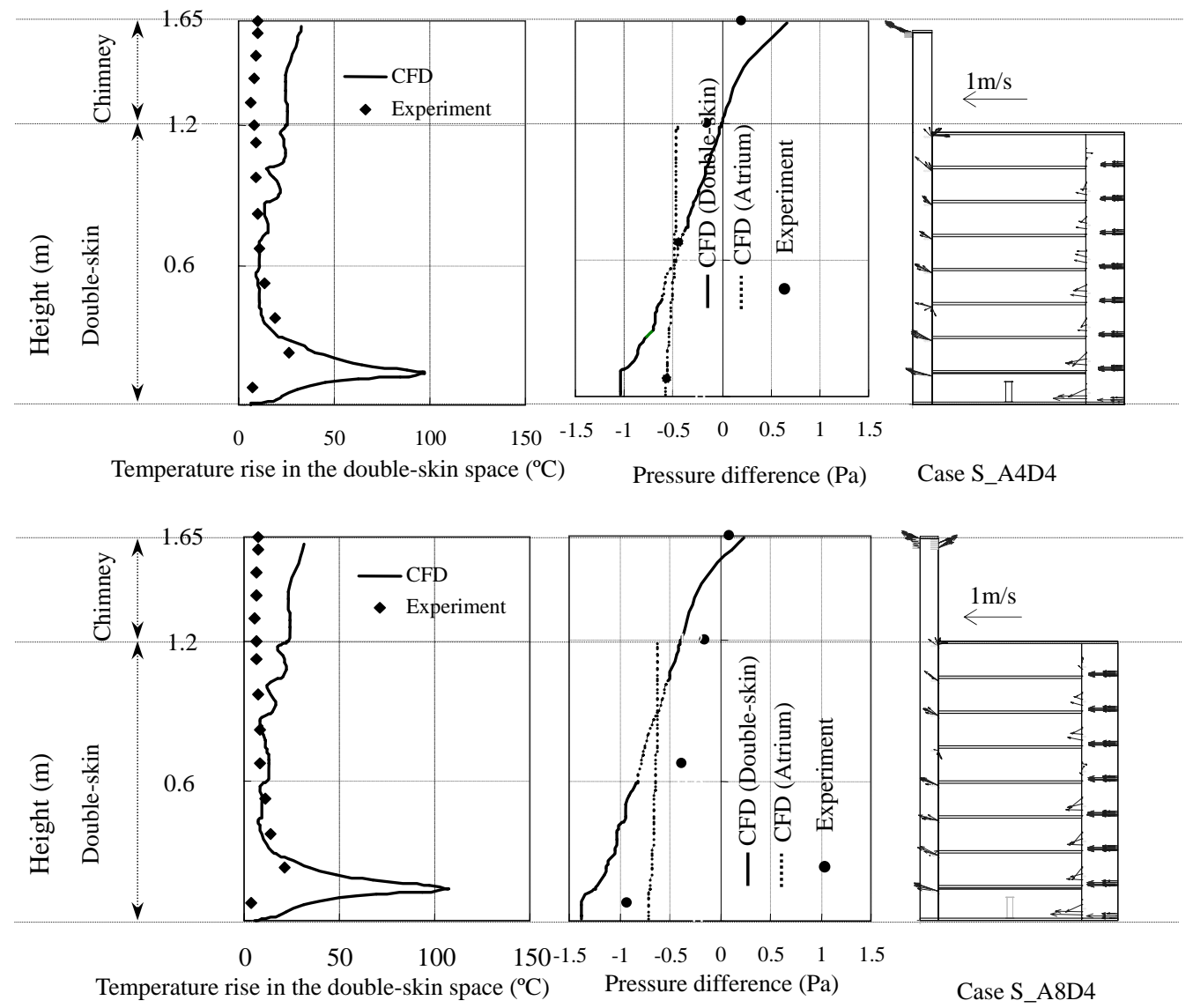

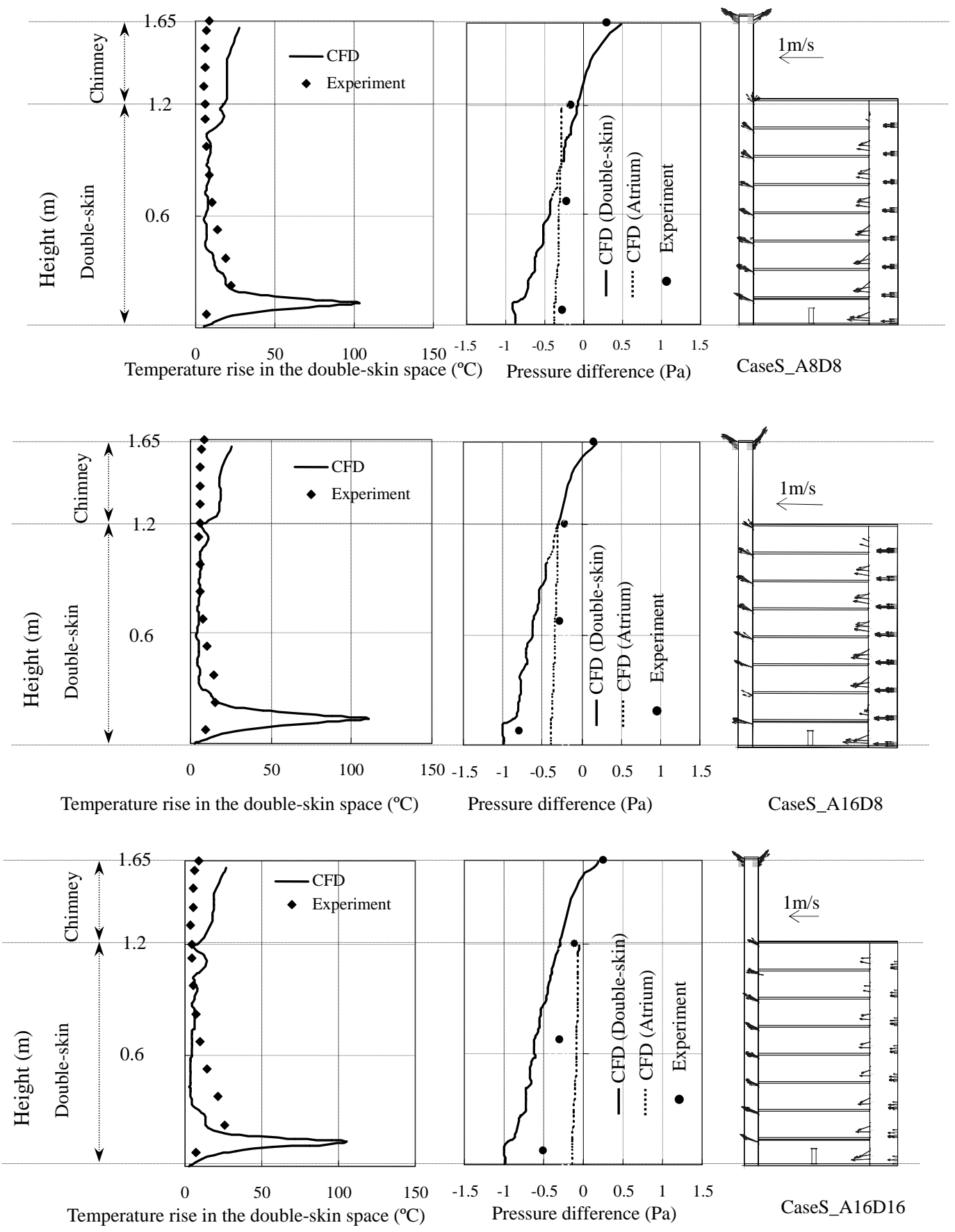

Fig. 6. Comparison of CFD and experimental results. 


\section{CONCLUSIONS}

Considering similarity of smoke movement and stack natural ventilation, possibility of using the natural ventilation system of a double-skin façade for smoke control is examined in this paper. Reduced scale model experiments and CFD analysis are conducted to unfold detail discussions. According to the results of CFD and experiments, when openings between outside and the atrium are set as $16 \mathrm{~m}^{2}\left(2 \mathrm{~m}^{2}\right.$ each floor), pressure of the double-skin space becomes greater than that of the atrium at any height of the occupant space. Although there are openings between the occupant space and double-skin space for the purpose of natural ventilation, smoke spread will be prevented. In addition preferable airflow in the occupant space even at the top floor can be also realized under such opening conditions. The possibility of using the natural ventilation system of a double-skin façade for smoke control is confirmed.

Of course there are many other parameters that will affect the natural ventilation and smoke control performance of the double skin space, such as the height of the solar chimney, the wind effect and so on. Further research will be carried on to discuss their influences.
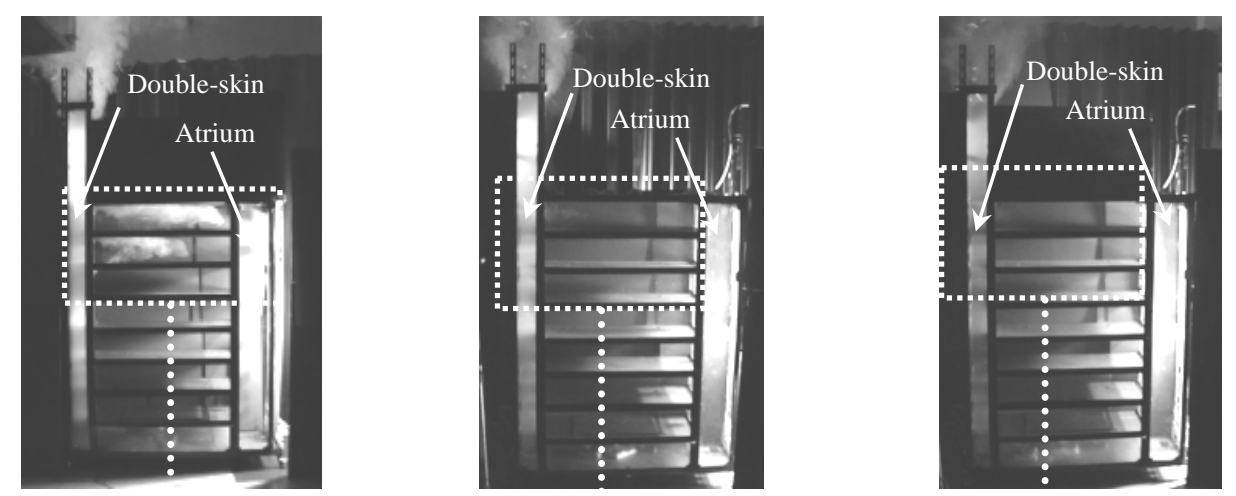

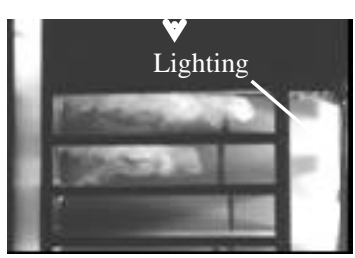

Case S_A4D4

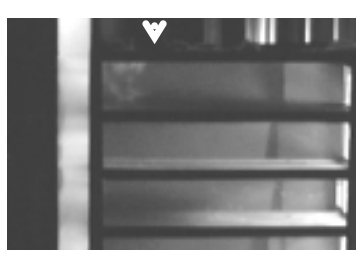

Case S_A8D8

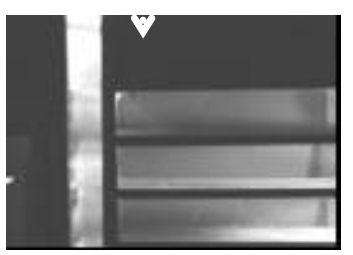

Case S_A16D16

Fig. 7. Visualized smoke movement in the experiments (upper: whole; lower: enlargement).

\section{ACKNOWLEDGMENTS}

This research was carried out with the support of the JSPS Science Promotion Fund No.13450241. The authors would like to thank Satoshi Nishimoto, Satoshi Tanaka, Yusuke Egawa and Naomi Okazawa of Waseda University for their hard work in the experiments. 


\section{REFERENCES}

[1] Gratia, E., and De Herde, A., "Optimal Operation of A South Double-skin Façade,” Energy and Buildings, 36, pp. 41-60, (2004).

[2] Gratia, E., and De Herde, A., "Is Day Natural Ventilation Still Possible in Office Buildings with A Double-skin Façade,” Building and Environment, 39, pp. 399-409, (2004).

[3] Jan Hensen, Martin Bartak, and Frantisek Drkal, "Modeling and Simulation of a Double-Skin Façade System,” ASHRAE Transactions (2002), Vol. 108, American Society of Heating, Refrigerating, and Air-Conditioning Engineers.

[4] Ding, W., Hasemi, Y., Minegishi, Y., and Yamada, T., "Smoke Control Based on a Solar Assisted Natural Ventilation System," Building and Environment, 39, pp. 775-782, July, 2004.

[5] Ding, W., Hasemi, Y., Minegishi, Y., and Yamada, T., "Compatibility of Natural Ventilation and Fire Safety in an Atrium Building with a Solar Chimney,” Transactions of AIJ No.569, pp. 1-7, 2003, (In Japanese).

[6] Ding, W., Hasemi, Y., and Yamada, T., "Natural Ventilation Performance of a Double-skin Façade,” Energy and Buildings, 37, (2005), pp. 411-418.

[7] McCaffrey, B.J., "Purely Buoyant Diffusion Flames: Some Experimental Results,” NBSIR 79-1910, National Bureau of Standards, 1979. 
